\title{
Updated checklist and identification of areas of endemism of benthic amphipods (Caprellidea and Gammaridea) from offshore habitats in the SW Gulf of Mexico*
}

IGNACIO WINFIELD ${ }^{1}$, ELVA ESCOBAR-BRIONES ${ }^{2}$ and JUAN J. MORRONE ${ }^{3}$

${ }^{1}$ Laboratorio de Ecología de Crustáceos, Facultad de Estudios Superiores Iztacala. Posgrado en Ciencias del Mar y Limnología-UNAM, A. P. 314, Tlalnepantla, C.P.54090, Estado de México, México. E-mail ignacioc@servidor.unam.mx

${ }_{2}^{2}$ Laboratorio de Biodiversidad y Macroecología, Instituto de Ciencias del Mar y Limnología-UNAM, A. P. 70-305, 04510, México, D.F., México.

${ }^{3}$ Museo de Zoología "Alfonso L. Herrera”, Departamento de Biología Evolutiva, Facultad de Ciencias-UNAM, A. P. 70-379, 04510, México, D.F., México.

SUMMARY: An updated checklist of the benthic amphipods associated with soft bottoms in the SW Gulf of Mexico has been made and the areas of endemism have been identified. Amphipods were collected in a depth interval of 25 to $3700 \mathrm{~m}$ during six cruises from 1994 to 1999 . A total number of 56 species were identified, 11 belonging to the suborder Caprellidea and 45 to the suborder Gammaridea. Thirteen species extended their geographical distribution within the Gulf of Mexico and four species were considered new records in the Gulf of Mexico. A biogeographic analysis based on the shared species and the parsimony criterion helped identify three areas of endemism in the SW Gulf of Mexico. They were named: area A, a small area on the continental shelf of the Bay of Campeche; area B, the continental slope of the Bay of Campeche; and area $\mathrm{C}$, the lower continental slope of the Mexican ridges extending into the western Sigsbee abyssal plain. These areas are defined in terms of their complex topography that may help isolate habitats that promote endemicity.

Keywords: Amphipoda, biogeography, continental shelf, continental slope, abyssal plain.

RESUMEN: LISTADO ACTUALIZADO E IDENTIFICACIÓN DE ÁREAS DE ENDEMISMO DE LOS ANFÍPODOS BENTÓNICOS (CAPRELLIDEA y GAMMARIDEA) DE HÁBITATS MARINOS EN EL SO DEL Golfo DE MÉXICO. - Se presenta una lista actualizada de los anfípodos bentónicos asociados a fondos suaves en el SO del Golfo de México y las áreas de endemismo reconocidas. Los anfípodos fueron colectados en un intervalo de profundidad de los 25 a $3700 \mathrm{~m}$ en seis cruceros oceanográficos de 1994 a 1999 . Un total de 56 especies fueron identificadas, 11 pertenecientes al suborden Caprellidea y 45 al suborden Gammaridea. Trece especies ampliaron su distribución geográfica en el Golfo de México y cuatro especies fueron registros nuevos para el Golfo de México. Un análisis biogeográfico basado sobre las especies compartidas de acuerdo con el criterio de parsimonia ayudó a identificar tres áreas de endemismo en el sector SO del Golfo de México, nombradas como área A, un área pequeña sobre la plataforma continental de la Bahía de Campeche; área B, el talud continental de la Bahía de Campeche; y área C, del talud continental inferior de las Cordilleras Mexicanas hasta el oeste de la planicie abisal de Sigsbee. Estas áreas fueron definidas en términos de su topografía compleja que permite aislar hábitats promoviendo el endemismo.

Palabras clave: Amphipoda, biogeografía, plataforma continental, talud continental, planicie abisal. 


\section{INTRODUCTION}

The first reports of amphipods from offshore habitats were documented during the last decades of the $19^{\text {th }}$ century by Sars, Chevreux, and Stebbing (Thurston, 2000). A large number of amphipods have been recorded subsequently in diverse benthic habitats (Barnard, 1961, 1962, 1964). Endemicity to the generic level was analyzed by Barnard and Karaman (1991) and Bellan-Santini (1990) within different biogeographic regions. At a worldwide scale, the surveys by Marquez and Bellan-Santini (1993), Cartes and Sorbe (1999), Bachelet et al. (2003), and Guerra-García (2003) have contributed with new species to the checklist, showing the restricted geographic distribution of species of this group.

Our knowledge of the amphipod fauna has significantly increased in the last years; however, it remains limited for offshore habitats in most of the ocean regions. The benthic amphipod fauna of the Gulf of Mexico has been extensively documented in the coastal ecosystems including the continental shelf (Myers, 1981; Ortiz, 1991; Thomas, 1993; LeCroy, 1995, 2000, 2001).

Our objective was to update the checklist of benthic amphipod species (Caprellidea and Gammaridea) occurring between 25 and $3700 \mathrm{~m}$ depth, and to recognize areas of endemism of amphipod fauna in the offshore habitats of the south-western region of the Gulf of Mexico.

\section{MATERIAL AND METHODS}

The Gulf of Mexico is characterized by a complex geomorphology (Roberts et al., 1999) with various canyons, escarpments, salt diapirs and massive carbonated deposits (Bryant et al., 1991). The semienclosed basin is linked with the Caribbean Sea by the Yucatan Channel and with the Western Tropical Atlantic Ocean through the Straits of Florida and the different straits and sills through the Caribbean Sea. The seafloor is an accumulation of terrigenous clastic sediments, the sedimentary regime is the result of the influence of the Mississippi, Panuco, Papaloapan and Grijalva-Usumacinta rivers (McKee and Baskaran, 1999).

The continental shelf represents approximately $30 \%$ of the total area (Rabalais et al., 1999) with a variable extension (Bouma, 1972). The continental slope is characterized by the Mexican ridges in the

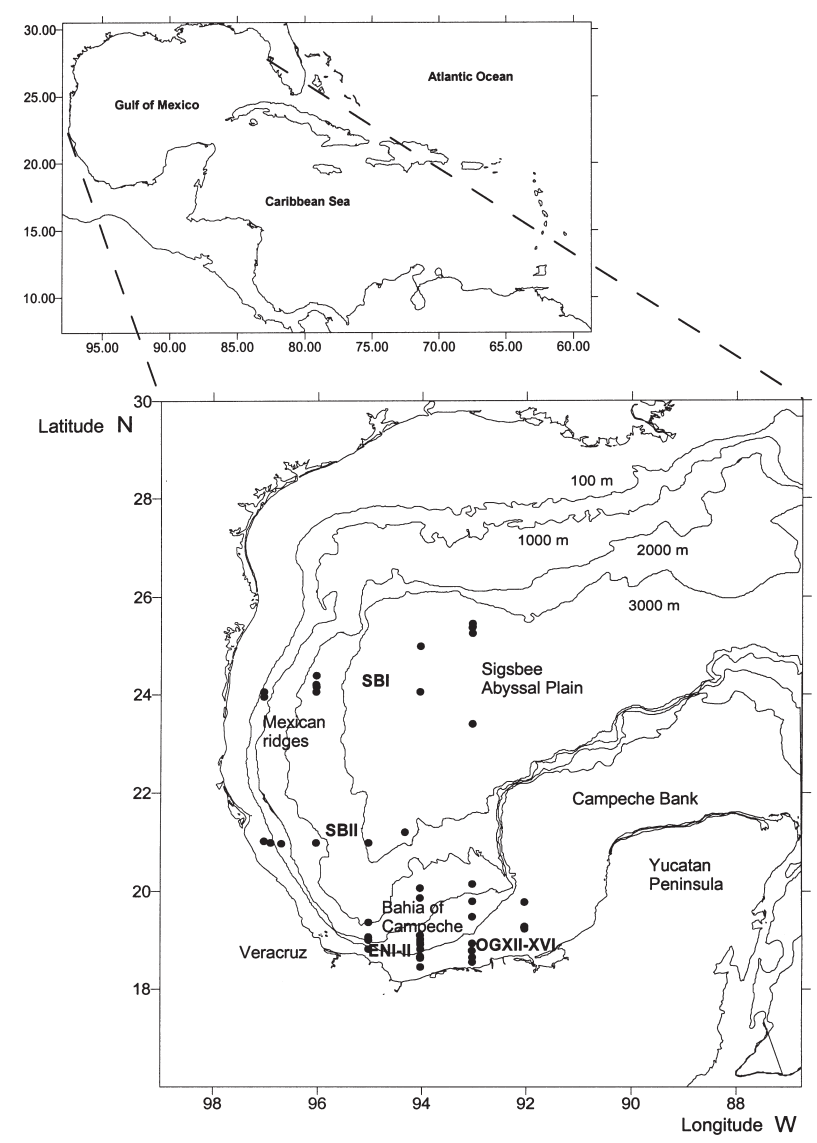

FIG. 1. - Markers show the location of sampling stations of the six cruises where amphipods were sorted for this study. Abbreviations used: SBI: Sigsbee I, SBII: Sigsbee II, ENI-II: ENOS I and II, OGXII-XVI: OGMEX XII and XVI.

western sector of the Gulf, a canyon and knolls in the Bay of Campeche, and an escarpment along the northern edge of the Campeche Bank. The Sigsbee abyssal plain occupies most of the central portion of the basin and is characterized by thin turbidite layers (Bryant et al., 1991). The surface circulation is dominated by the Loop Current and interaction with eddies (Welsh and Inoue, 2000), in general the water column is thermally stratified and displays space and time variability along the continental shelf (Monreal-Gómez and Salas de León, 1997).

The amphipod species were sorted out by sieving, with a $250 \mu \mathrm{m}$ sieve, superficial sediment samples that were collected with GOMEX (0.06 $\left.\mathrm{m}^{2}\right)$ and USNEL $\left(0.25 \mathrm{~m}^{2}\right)$ boxcorers on six cruises: SIGSBEE.1 (SBI), SIGSBEE.2 (SBII), ENOS.1 (ENI), ENOS.2 (ENII), OGMEX.12 (OGXII), and OGMEX.16 (OGXVI). These cruises were in the south-western (SW) region of the GM in the polygon delimited by $18^{\circ} 38.0^{\prime}$ and $25^{\circ} 27.0^{\prime} \mathrm{N}-92^{\circ} 19.0^{\prime}$ and $97^{\circ} 12.0^{\prime} \mathrm{W}$ on board the 
R/V Justo Sierra-UNAM from 1994 to 1999. The bathymetric range $(25$ to $3700 \mathrm{~m}$ ) encompassed soft bottom habitats of the continental shelf, continental slope and abyssal plain. Sampling sites were graphically posted with the SURFER V.7 software. Caprellidea and Gammaridea amphipods were preserved in ethanol solution, and identified according to McCain (1968), Myers (1981), Lowry (1984), Barnard and Karaman (1991), Ortiz (1994), Bousfield and Hoover (1997), Lowry and Stoddart (1997), LeCroy (2000, 2001), and Ortiz et al. (2002). The classification and the superfamily arrangement followed Bousfield and Shih (1994) and Bousfield (2001). Incomplete or damaged amphipods were identified to the lowest taxonomic level possible. Each species herein reported includes the geographical occurrence, the information for depth and sediment type and the cruises on which they were collected. The specimens were characterized by their frequency and abundance of occurrence in the samples and herein named as dominant, common and rare faunal components. The specimens are deposited at the Colección Nacional de Crustáceos (CNCRUNAM) and counted with a reference number to the database and collection.

Endemicity in this study was defined as local areas with high survival of species (allochthonous endemics) (Pielou, 1992). The Parsimony Analysis of Endemicity (PAE) was used to identify the areas of endemism in the SW region of GM. This method classifies the study sites according to their shared taxa, following the parsimony criterion (Rosen, 1988; Morrone, 2004). To obtain the cladograms and the strict consensus cladogram WINCLADA V 0.9.99 beta (Nixon, 1999) cladistic software was used. The data matrix (which can be requested from the first author) included 40 species (columns) that were identified as 0 to 39 , collected in 15 sites (rows) that were identified as $\mathrm{S} 1$ to $\mathrm{S} 15$ (between 25 and $3635 \mathrm{~m}$ depth). The amphipods used in the data matrix included six caprellids and 34 gammarids. The amphipod information was coded as binary characters; presence of the amphipod was equal to 1 and its absence equal to 0 (Morrone, 1994). A hypothetic area was added ( 0 in all columns) to root the cladograms. The effects of sampling intensity and spatial autocorrelation were not considered in the findings. The areas of endemism identified were overlapped on the locations sampled.

\section{RESULTS}

Order AMPHIPODA Latreille, 1816

Suborder CAPRELLIDEA Leach, 1814

Superfamily CAPRELLOIDEA Laubitz, 1993

Family CAPRELLIDAE White, 1847

1. Caprella sp.

This species is a common component, it occurs in soft bottoms of the Mexican ridges (SBI cruise) and the Bay of Campeche (OGXVI cruise) within a depth range of 550 to $2120 \mathrm{~m}$.

\section{Caprella danilevskii Czerniavski, 1868}

This species is a dominant component, it occurs in muddy sediments of the Mexican ridges (SBI cruise) within a depth range of 550 to $2120 \mathrm{~m}$.

\section{Caprella equilibra Say, 1818}

This species is a dominant component, it occurs in muddy sediments of the Mexican ridges and Sigsbee abyssal plain (SBI cruise) within a depth range of 1231 to $3700 \mathrm{~m}$.

\section{Caprella penantis Leach, 1814}

This species is a dominant component, it occurs in muddy sediments of the Sigsbee abyssal plain (SBI cruise) within a depth range of 2200 to $3700 \mathrm{~m}$.

\section{Family PARIAMBIDAe Laubitz, 1993 5. Deutella sp.}

This species is a rare component, it occurs in soft bottoms of the Bay of Campeche (OGXVI cruise) at 897 m depth.

\section{Deutella incerta (Mayer, 1903)}

This species is a rare component, it occurs in soft bottoms of the Bay of Campeche (OGXVI and ENII cruises) within a depth range of 116 to $1470 \mathrm{~m}$.

\section{Hemiaegina minuta Mayer, 1890}

This species is a rare component, it occurs in soft bottoms of the Bay of Campeche (OGXVI cruise) at $354 \mathrm{~m}$ depth. 
This species is a rare component, it occurs in muddy sediments of the Mexican ridges (SBI cruise) at $498 \mathrm{~m}$ depth.

Family Phtisicidae Vassilenko, 1968

9. Hemiproto wigleyi McCain, 1968

This species is a rare component, it occurs in soft bottoms of the Veracruz continental shelf (SBII cruise) and the Bay of Campeche (OGXVI cruise) within a depth range of 25 to $76 \mathrm{~m}$.

\section{Phtisica sp.}

This species is a rare component, it occurs in soft bottoms of the Veracruz continental shelf (SBII cruise) at $76 \mathrm{~m}$ depth.

\section{Phtisica marina Slabber, 1769}

This species is a rare component, it occurs in soft bottoms of the Bay of Campeche (OGXVI and ENII cruises) within a depth range of 76 to $1470 \mathrm{~m}$.

Suborder GAMMARIDEA Latreille, 1803 Superfamily AMPELISCOIDEA Bousfield, 1979

Family AMPELISCIDAE Costa, 1857

\section{Ampelisca sp.}

This species is a dominant component, it occurs in muddy sediments and sandy bottoms of the Veracruz continental shelf (SBII cruise) and Bay of Campeche (OGXII and OGXVI cruises) within a depth range of 25 to $203 \mathrm{~m}$.

\section{Ampelisca agassizi (Judd, 1896)}

This species is a common component, it occurs in sandy bottoms of the Bay of Campeche (OGXVI cruise) at $25 \mathrm{~m}$ depth.

\section{Ampelisca bicarinata Goeke and Heard, 1983}

This species is a common component, it occurs in muddy sediments and sandy bottoms of Tamaulipas continental shelf (SBI cruise) and the Bay of Campeche (OGXII and OGXVI cruises) within a depth range of 47 to $203 \mathrm{~m}$.
This species is a common component, it occurs in soft bottoms of the Tamaulipas continental shelf (OGXVI cruise) within a depth range of 169 to $203 \mathrm{~m}$.

\section{Ampelisca parapacifica Goeke and Heard, 1984}

This species is a common component, it occurs in muddy sediments and sandy bottoms of the Bay of Campeche (OGXII and OGXVI cruises) within a depth range of 26 to $169 \mathrm{~m}$.

\section{Ampelisca vadorum Mills, 1963}

This species is a common component, it occurs in sandy bottoms of the Bay of Campeche (OGXVI cruise) at $25 \mathrm{~m}$ depth.

\section{Ampelisca verrilli Mills, 1967}

This species is a common component, it occurs in muddy sediments and sandy bottoms of the Bay of Campeche (OGXVI cruise) within a depth range of 25 to $200 \mathrm{~m}$.

\section{Byblis sp.}

This species is a rare component, it occurs in soft bottoms of the Bay of Campeche (ENII cruise) at $1611 \mathrm{~m}$ depth.

Superfamily COROPHIOIDEA Barnard and Barnard, 1983

Family AORIDAE Stebbing, 1899 20. Lembos sp. s. $s$.

This species is a rare component, it occurs in soft bottoms of the Veracruz continental shelf (SBII cruise) and the Bay of Campeche (ENII cruise) within a depth range of 76 to $314 \mathrm{~m}$.

Family COROPHIIDAE Dana, 1849

Subfamily COROPHIINAE Bousfield and Hoover, 1997

\section{Apocorophium acutum (Chevreux, 1908)}

This species is a rare component, it occurs in soft bottoms of the Sigsbee abyssal plain (SBI cruise) at $3600 \mathrm{~m}$ depth. 
22. Apocorophium simile (Shoemaker, 1934)

This species is a rare component, it occurs in soft bottoms of the Mexican ridges (SBI cruise) at 1231 m depth.

\section{Corophium sp.}

This species is a dominant component, it occurs in soft bottoms of the Tamaulipas continental shelf, the Mexican ridges and the Sigsbee abyssal plain (SBI cruise) and sandy sediments of the Bay of Campeche (OGXVI cruise) within a depth range of 25 to $3700 \mathrm{~m}$.

\section{Monocorophium acherusicum (Costa, 1851)}

This species is a rare component, it occurs in soft bottoms of the Sigsbee abyssal plain (SBI cruise) at $2620 \mathrm{~m}$ depth.

\section{Monocorophium insidiosum (Crawford, 1937)}

This species is a rare component, it occurs in soft bottoms of the Mexican ridges (SBI cruise) at 1231 m depth.

Family IsAEDIDAE Dana, 1855

26. Photis sp.

This species is a rare component, it occurs in sandy sediments of the Bay of Campeche (ENII cruise) at $25 \mathrm{~m}$ depth.

Family IsCHYROCERIDAE Stebbing, 1899

\section{Cerapus sp.}

This species is a rare component, it occurs in sandy sediments of the Bay of Campeche (ENII cruise) at $25 \mathrm{~m}$ depth.

\section{Ericthonius sp.}

This species is a common component, it occurs in soft bottoms of the Mexican ridges (SBI cruise) within a depth range of 498 to $1698 \mathrm{~m}$.

\section{Ericthonius brasiliensis (Dana, 1853)}

This species is a rare component, it occurs in soft bottoms of the Sigsbee abyssal plain (SBI cruise) at $3690 \mathrm{~m}$ depth.
Family PoDOCERIDAE Leach, 1814

\section{Podocerus sp.}

This species is a common component, it occurs in soft bottoms of the Mexican ridges and the Sigsbee abyssal plain (SBI cruise) within a depth range of 1231 to $3700 \mathrm{~m}$.

Superfamily EusiROIDEA Bousfield, 1979

Family BATEIDAE Stebbing, 1906

31. Carinobatea cuspidata Shoemaker, 1926

This species is a rare component, it occurs in sandy sediments of the Bay of Campeche (OGXVI cruise) at $52 \mathrm{~m}$ depth.

\section{Family EusIRIDAE Stebbing, 1888} 32. Eusiroides sp.

This species is a rare component, it occurs in soft bottoms of the Bay of Campeche (OGXVI cruise) at $203 \mathrm{~m}$ depth.

Superfamily LeUCOTHOIDEA Bousfield, 1979

Family MAXILLIPIIDAE Ledoyer, 1973

33. Maxillipius sp.

This species is a rare component, it occurs in soft bottoms of the Veracruz continental shelf (SBII cruise) at $76 \mathrm{~m}$ depth.

Superfamily LILJEBORGIOIDEA Bousfield, 1979

Family LILJEBORGIIDAE Stebbing, 1899

34. Liljeborgia sp.

This species is a rare component, it occurs in sandy sediments of the Bay of Campeche (OGXII and OGXVI cruises) within a depth range of 57 to $65 \mathrm{~m}$.

Superfamily LySIANASSOIDEA Lowry and Stoddart, 1997

Family LySIANASSIDAE Dana, 1849

Subfamily LysianASSINAE Dana, 1849

35. Concarnes sp.

This species is a rare component, it occurs in soft bottoms of the Mexican ridges (SBI cruise) at $498 \mathrm{~m}$ depth.

\section{Concarnes concavus (Shoemaker, 1933)}

This species is a rare component, it occurs in soft 
bottoms of the Bay of Campeche (ENII cruise) at $256 \mathrm{~m}$ depth.

Subfamily TRYPHOSINAE Lowry and Stoddart, 1997 37. Hippomedon sp.

This species is a rare component, it occurs in soft bottoms of the Bay of Campeche (OGXII and OGXVI cruises) within a depth range of 26 to $203 \mathrm{~m}$.

Superfamily Oedicerotoidea Bousfield, 1979

Family OEDICEROTIDAE Lilljeborg, 1865

\section{Americhelidium sp.}

This species is a rare component, it occurs in sandy sediments soft bottoms of the Bay of Campeche (OGXVI cruise) at $25 \mathrm{~m}$ depth.

39. Americhelidium americanum (Bousfield, 1973)

This species is a rare component, it occurs in soft bottoms of the Veracruz continental shelf (SBII cruise) at $76 \mathrm{~m}$ depth.

\section{Hartmanodes sp.}

This species is a rare component, it occurs in sandy sediments of the Bay of Campeche (OGXII cruise) at $25 \mathrm{~m}$ depth.

\section{Perioculodes sp.}

This species is a rare component, it occurs in soft bottoms of the Bay of Campeche (OGXVI cruise) at $61 \mathrm{~m}$ depth.

Superfamily PARDAliscoidea Bousfield, 1979

Family PARDALISCIDAE Boeck, 1871

\section{Halice sp.}

This species is a rare component, it occurs in soft bottoms of the Bay of Campeche (ENII cruise) at $878 \mathrm{~m}$ depth.

Superfamily Phoxocephaloidea Bousfield, 1979

Family Phoxocephalidae Sars, 1895

Subfamily BRolginae Barnard and Drummond, 1978

\section{Eobrolgus sp.}

This species is a common component, it occurs in soft bottoms of the Bay of Campeche (OGXVI,
ENI and ENII cruises) within a depth range of 25 to $1800 \mathrm{~m}$.

\section{Eobrolgus spinosus (Holmes, 1905)}

This species is a common component, it occurs in soft bottoms of the Bay of Campeche (OGXII and ENII cruises) within a depth range of 200 to $1290 \mathrm{~m}$.

Subfamily HaRPINIINAE Barnard and Drummond, 1978

\section{Harpinia sp.}

This species is a dominant component, it occurs in soft bottoms of the Bay of Campeche (SBII, OGXII, OGXVI and ENII cruises) within a depth range of 25 to $3360 \mathrm{~m}$.

\section{Pseudharpinia sp.}

This species is a rare component, it occurs in soft bottoms of the Bay of Campeche (SBII, ENI and ENII) within a depth range of 600 to $3360 \mathrm{~m}$.

Subfamily Metharpininae Jarret and Bousfield, 1994

\section{Metharpinia sp.}

This species is a rare component, it occurs in soft bottoms of the Bay of Campeche (ENI and ENII cruises) within a depth range of 200 to $1140 \mathrm{~m}$.

48. Metharpinia floridana (Shoemaker, 1933)

This species is a dominant component, it occurs in soft bottoms of the Bay of Campeche (SBII, OGXII, OGXVI, ENI and ENII cruises) within a depth range of 25 to $3360 \mathrm{~m}$.

Superfamily PonTOPOREIOIDEA Bousfield, 1979

Family HAUSTORIIDAE Stebbing, 1906 49. Haustorius sp.

This species is a rare component, it occurs in sandy sediments of the Bay of Campeche (OGXII cruise) at $25 \mathrm{~m}$ depth.

\section{Parahaustorius holmesi Bousfield, 1965}

This species is a rare component, it occurs in sandy sediments of the Bay of Campeche (OGXVI cruise) at $25 \mathrm{~m}$ depth. 


\section{Protohaustorius sp.}

This species is a rare component, it occurs in soft bottoms of the Bay of Campeche (ENII cruise) at $1140 \mathrm{~m}$.

Superfamily STENOTHOIDEA Bousfield, 2001

Family AMPHILOCHIDAE Boeck, 1871

Subfamily AMPHILOCHINAE Barnard and Karaman, 1991

52. Hourstonius tortugae (Shoemaker, 1933)

This species is a rare component, it occurs in soft bottoms of the Bay of Campeche (ENII cruise) at $879 \mathrm{~m}$ depth.

\section{Family StenOTHOIDAE Boeck, 1871 53. Stenothoe sp.}

This species is a dominant component, it occurs in soft bottoms of the Mexican ridges and Sigsbee abyssal plain (SBI cruise) within a depth range of 498 to $3700 \mathrm{~m}$.

\section{Stenothoe gallensis Walker, 1904}

This species is a rare component, it occurs in soft bottoms of the Sigsbee abyssal plain (SBI cruise) at $3635 \mathrm{~m}$ depth.

\section{Superfamily SyNOPIOIDEA Bousfield, 1979 \\ Family SYNopIIDAE Dana, 1855}

\section{Garosyrrhoe sp.}

This species is a rare component, it occurs in soft bottoms of the Veracruz continental shelf (SBII cruise) at $76 \mathrm{~m}$ depth.

\section{Syrrhoe sp.}

This species is a rare component, it occurs in soft bottoms of the Bay of Campeche (ENI cruise) at $1800 \mathrm{~m}$ depth.

\section{Areas of endemism}

The Parsimony Analysis of Endemicity provided 20 cladograms. The strict consensus cladogram (SCC) has 51 steps, with 33 sinapomorphies, 16 parallelisms, and two reversals (Fig. 2). Three areas of endemism were identified in the strict consensus cladogram in the SW Gulf of Mexico that were

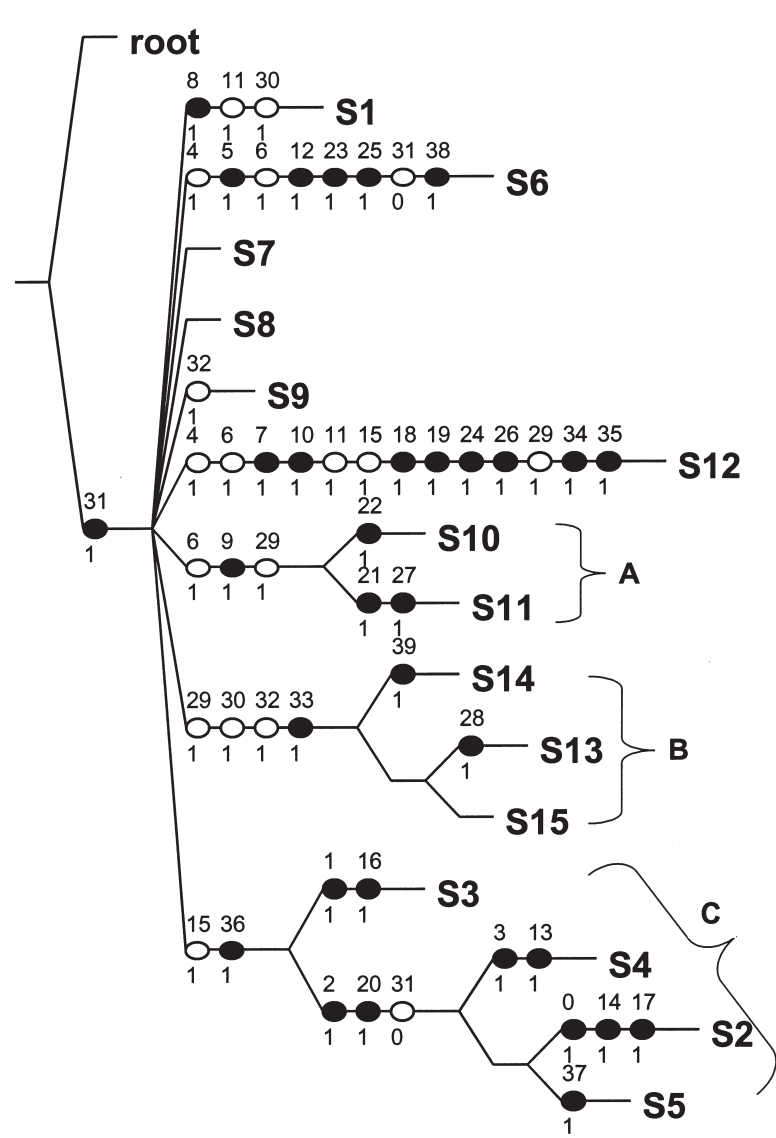

Fig. 2. - Strict consensus cladogram calculated from the Parsimony Analysis of Endemicity (PAE) showing the three areas of endemism. Area A with four sinapomorphies: (9) Ampelisca parapacifica, (22) Hippomedon sp., (21) Liljeborgia sp., and (27) Perioculodes sp.; area B with three sinapomorphies: (33) Metharpinia floridana, (39) Syrrhoe sp., and (28) Halice sp., and area C with 11 sinapomorphies: (36) Stenothoe sp., (37) S. gallensis., (0) Caprella sp., (1) C. danilevskii, (2) C. equilibra, (3) C. penantis, (16) Monocorophium acherusichum, (17) M. insidiosum, (13) Apocorophium acutum, (14) A. simile, and (20) Podocerus sp.

named as area A, a small area on the continental shelf of the Bay of Campeche, between 26 and $65 \mathrm{~m}$ depth (sinapomorphies: Ampelisca parapacifica, Hippomedon sp., Liljeborgia sp., and Perioculodes sp.); area $\mathrm{B}$, the continental slope of the Bay of Campeche, between 878 and 1270 m depth (sinapomorphies: Metharpinia floridana, Syrrhoe sp., and Halice sp.); and area C, the lower continental slope of the Mexican ridges extending into the western Sigsbee abyssal plain, between 1231 and $3635 \mathrm{~m}$ depth (sinapomorphies: Stenothoe sp., S. gallensis., Caprella sp., C. danilevskii, C. equilibra, C. penantis, Monocorophium acherusichum, M. insidiosum, Apocorophium acutum, A. simile, and Podocerus sp.) (Fig. 3).

According to PAE and SCC, about $60 \%$ of the difference between groups is accounted for by most species occurring at nine localities. Most of the ben- 


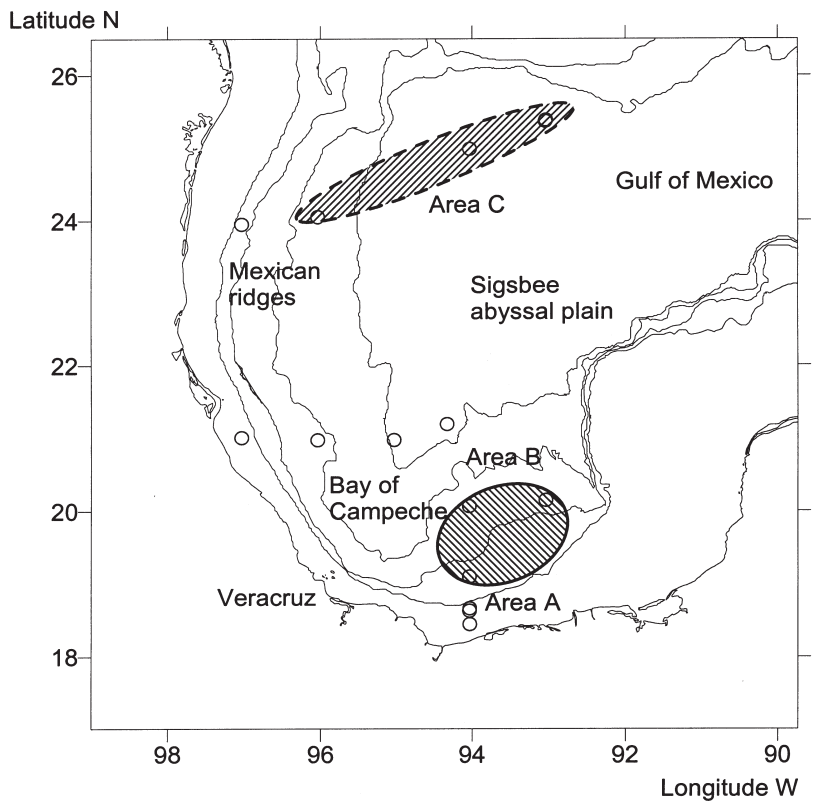

FIG. 3. - Areas of endemism in the SW region of the Gulf of Mexico overlain with the sampling stations used to build the strict consensus cladogram.

thic amphipod species are endemic to the continental slope and abyssal plain (25\%) and in overall, the Gulf of Mexico has $32 \%$ endemism (or 18 species) of the 56 benthic amphipods reported in this study, and $6.5 \%$ of endemic species of the Atlantic Ocean (279 species) (Thurston, 2000).

\section{DISCUSSION}

\section{New records and geographical extension}

This study contributes with 56 species that are grouped into 21 families and 13 superfamilies of the suborders Caprellidea and Gammaridea in the SW of GM. Ampelisca sp., Corophium sp., Cerapus sp., Concarnes sp., Harpinia sp., Maxillipius sp. and Stenothoe sp. will require a future taxonomic analysis once this larger collection of specimens is accounted for. The distribution of 13 amphipod species originally recorded for the northern GM is geographically and bathymetrically extended into the Bay of Campeche (Table 1). The occurrence of Caprella danilevskii, C. penantis and Stenothoe gallensis on the continental slope and the abyssal plain can be explained by sediment transport and turbidity currents. Other species (Hemiproto wigleyi, Carinobatea cuspidata, Parahaustorius holmesi, and Americhelidium americanum) extend their geographic distribution southwards. Other coastal species have also been recorded on the continental shelf (Ampelisca lobata, Hourstonius tortugae, and Concarnes concavus) and the continental slope (Phtisica marina). The family Corophiidae is one of the cases previously known from coastal habitats (Bousfield, 2000) and extending into the continental slope (Apocorophium simile and Monocorophium insidiosum), and abyssal plain (Apocorophium acutum, Corophium sp. and Monocorophium acherusicum).

New records of genera not previously recorded in the GM included Maxillipius sp. on the continental shelf with sister species M. rectitelson Ledoyer, 1973 in Madagascar and M. commensalis Lowry, 1984 in Papua New Guinea (Lowry, 1984), Halice sp. on the continental slope with 15 sister species (Barnard and Karaman, 1991) in the western sector. The presence of Syrrhoe sp. on the continental slope of the Bay of Campeche with 13 sister species, a close relative being S. papyracea Stebbing, 1888 from the Caribbean Sea (Barnard and Karaman, 1991) and Pseudharpinia sp. on the continental slope as well as the other two records of genera in the GM.

A total number of 101 species of caprellid and gammaridean amphipods, grouped into 26 families, were recorded by Escobar-Briones and Winfield (2003) on the continental shelf and upper continental slope and they recognized that the greatest species richness (ca. 70\%) occurred in the $\mathrm{N}$ and $\mathrm{E}$ Gulf of Mexico regions. These new records, which extend into the lower continental slope and abyssal plain, have increased by 41 species the known number of species and by six the number of known families. A larger effort has been made since 1997 solely in the abyssal plain habitats and may provide in the coming years new unexpected records.

\section{Areas of endemism}

Area A is considered controversial in this study owing to its small size and the exclusion of other sampling sites also located on the shelf of the Bay of Campeche. The marked seasonal influence of rivers and the resulting sedimentary texture would suggest that the distribution of the amphipod components could fluctuate from widespread to local over the long term.

The family Phoxocephalidae occurs frequently and in high abundance in area B in the continental slope of the Bay of Campeche, where species of the slope genera Halice sp., Syrrhoe sp., Pseudharpinia sp., Harpinia sp. occur. 
TABLE 1. - Species of benthic amphipods that extend their geographical range within and into the Gulf of Mexico. Information includes the sector of previous record, the sector of new occurrence, the reported depth range, the new depth interval and the reference.

\begin{tabular}{|c|c|c|c|c|c|}
\hline Species & $\begin{array}{l}\text { Sector for the } \\
\text { new record }\end{array}$ & $\begin{array}{c}\text { Sector of } \\
\text { previous record }\end{array}$ & $\begin{array}{l}\text { New depth } \\
\text { interval }\end{array}$ & $\begin{array}{l}\text { Depth of occurrence } \\
(\mathrm{m})\end{array}$ & Reference \\
\hline Caprella danilevskii & SW & $\mathrm{NE}$ & $550-2120$ & $<200$ & McCain (1968) \\
\hline Caprella penantis & SW & NE, NW & $2200-3700$ & $<200$ & McCain (1968) \\
\hline Hemiproto wigleyi & SW & NE & $<200$ & $<200$ & McCain (1968) \\
\hline Phtisica marina & SW & $\mathrm{NE}$ & $76-1470$ & $<200$ & McCain (1968) \\
\hline Ampelisca lobata & SW & $\mathrm{NE}$ & $<200$ & $<200$ & LeCroy (2001) \\
\hline Hourstonius tortugae & SW & $\mathrm{NE}$ & 879 & $<200$ & LeCroy (2001) \\
\hline Carinobatea cuspidata & SW & $\mathrm{NE}$ & $<200$ & $<200$ & Ortiz (1991) \\
\hline Apocorophium acutum & SW & $\mathrm{NE}$ & 3600 & $<200$ & Bousfield (2001) \\
\hline Monocorophium insidiosum & SW & $\mathrm{NE}$ & 1231 & $<200$ & Bousfield (2001) \\
\hline Parahaustorius holmesi & SW & $\mathrm{NE}$ & $<200$ & $<200$ & LeCroy (2001) \\
\hline Concarnes concavus & SW & $\mathrm{NE}$ & 256 & $<200$ & Lowry and Stoddart (1997) \\
\hline Americhelidium americanum & SW & $\mathrm{NE}$ & $>200$ & $<200$ & LeCroy (2001) \\
\hline Stenothoe gallensis & SW & $\mathrm{NE}$ & 3635 & $<200$ & Thomas(1993) \\
\hline
\end{tabular}

Phoxocephalids (a primitive group) radiated successfully in shallower waters and colonized bathyal and abyssal depths before continental drift took place (Bousfield, 1982). Dispersion and speciation models for phoxocephalid amphipods are controversial and widely debated (Barnard and Drummond, 1978; Jarret and Bousfield, 1994); however, there is a coincidence between allopatrid speciation (vicariance) and the dispersion of this group towards the Western Atlantic. The incursion of Harpinia and Metharpinia into the Western Atlantic and the GM has been explained by the "post-Pangea" general model, with a centre of diversity in bathyal depths of the north-eastern Pacific (Jarret and Bousfield, 1994). Additionally, the presence of Halice sp., Byblis sp., Syrrhoe sp., Pseudharpinia sp. (primitive swimming forms), and Lembos sp. s.s. (primitive non-swimming aorid form), characteristic of bathyal and abyssal depths (Myers, 1981; Barnard and Karaman, 1991), fosters a new supposition about the GM and reinforces the hypothesis that the Bay of Campeche is an area with a high degree of endemism and greater biodiversity of natantia forms. Moreover, the broad protection in the marsupium, the fossorial condition, small body size, and direct development might represent endemicity evolutionary advantages for benthic amphipods. The patterns of origination and extinction that determine the current results are not biased by possible sampling artifacts (Miller, 2000), as we measured within-habitat rather than cumulative regional species richness and endemicity.

Area $\mathrm{C}$ has been recognized by the changes in sediment grain size that varies from inshore sandier substrates to offshore silt and clay sediments (Escobar-Briones et al., 1999). In addition to all the species and families (Caprellidae, Corophiidae and Stenothoidae) occurring in the Mexican ridge area there were frequent and abundant components. Variability (> 90\%) in amphipod richness may be explained by habitat heterogeneity with secondary contributions from the net primary productivity exported as biogenic carbon to the seafloor in the area. Habitat heterogeneity relates to the total species richness at the regional level through species turnover. The exported biogenic carbon contribution represents a resource and can be important to species when its main role has an influence on the habitat characteristics e.g. minimum oxygen zone on the slope and high export rates on the continental margin.

Corophids and caprellids have been documented in coastal ecosystems in the northern GM (McCain, 1968; Myers, 1981; Bousfield, 2000; LeCroy, 2000). The distribution of these amphipods in deeper habitats of the northern GM suggests a later incursion of the reptantia species by sediment dumping during the Tertiary (Bouma and Roberts, 1990), or by continuous transport events from shallower waters caused by turbidity currents (Roberts et al., 1999). Similar sediment transport can occur in the Mexican Ridges promoting continuous transport of shallower species to deeper waters.

\section{ACKNOWLEDGEMENTS}

For comments and suggestions we thank M. Ortiz, Universidad de la Habana, and many undergraduate and graduate students that have sorted out the amphipods from the sediment samples for years and made this study possible. Program PASPA (DGAPA-UNAM) and projects PAPIIT IN224503; IN211200; SEP-CONACyT 2002 Clave 40158, CONACyT G-27777B granted to E. Escobar supported shiptime onboard UNAM's R/V Justo Sierra. 


\section{REFERENCES}

Bachelet, G., J.C. Dauvin and J.C. Sorbe. - 2003. An updated checklist of marine and brackish water Amphipoda (Crustacea : Peracarida) of the southern Bay of Biscay. Cah. Biol. Mar., 44: 121-151.

Barnard, J.L. - 1961. Gammaridean Amphipoda from depths of 400 to 6000 meters. Galathea Rep., 5: 23-128.

Barnard, J.L. - 1962. South Atlantic abyssal amphipods collected by R.V. Vema. Abyssal Crustacea. Vema Res. Ser., 1: 1-78.

Barnard, J.L. - 1964. Deep-Sea Amphipoda (Crustacea) collected by the R.V. Vema in the eastern Pacific Ocean and the Caribbean and Mediterranean seas. Bull. Amer. Mus. Nat. Hist., 127(1): 1-46.

Barnard, J.L. and M.M. Drummond. - 1978. Gammaridean Amphipoda of Australia, Part III: The Phoxocephalidae. Smithsonian Contrib. Zool., 245: 1-551.

Barnard, J.L. and Karaman G.S. - 1991. The families and genera of marine Gammaridean Amphipoda (except marine Gammaroids). Rec. Austr. Mus., Parts I and II (Supl. 13).

Bellan-Santini, D. - 1990. Mediterranean deep-sea Amphipoda: composition, structure and affinities of the fauna. Prog. Oceanogr., 24: 275-387.

Bouma, H.A. - 1972. Distribution of sediments and sedimentary structures in the Gulf of Mexico. In: R. Resak and V. Henry (eds), Contribution on the Geological and Geophysical Oceanography of the Gulf of Mexico, pp. 35-65. Texas A and M University Oceanographic Studies, Houston.

Bouma, H.A. and H.H. Roberts. - 1990. Northern Gulf of Mexico slope. Geol. Mar. Letter, 10: 177-181.

Bousfield, E.L. - 2000. Biogeographical analysis of gammaridean amphipod faunas based on their phyletic classification. Pol. Arch. Hydrobiol., 47(3-4): 335-351.

Bousfield, E.L. - 2001. An updated commentary on phyletic classification of the amphipod Crustacea and its applicability to the North American fauna. Amphipacifica, 3(1): 49-119.

Bousfield, E.L. and P.M. Hoover. - 1997. The amphipod family Corophiidae on the Pacific coast of North America. Part V. Corophiinae, new subfamily. Systematics and distributional ecology. Amphipacifica, 2(3): 67-139.

Bousfield, E.L. and C.T. Shih. - 1994. The phyletic classification of amphipod crustaceans: problems in resolution. Amphipacifica, 1(3): 76-134.

Bryant, W.R., J. Lugo, C. Córdoba and A. Salvador. - 1991. Physiography and bathymetry. In: A. Salvador (ed), The Geology of North America, the Gulf of Mexico basin, pp. 13-30, Volume J. Geological Society of America, USA.

Cartes, J.E. and J.C. Sorbe. - 1999. Deep-water amphipods from the Catalan Sea slope (western Mediterranean): Bathymetric distribution, assemblage composition and biological characteristics. J. Nat. Hist., 33(8): 1133-1158.

Escobar-Briones, E. and I. Winfield. - 2003. Checklist of the benthic Gammaridea and Caprellidea (Crustacea: Peracarida: Amphipoda) from the Gulf of Mexico continental shelf and slope. Belg. J. Zool., 133(1): 37-44.

Escobar-Briones, E.., M. Signoret and D. Hernández. - 1999. Variación de la densidad de la infauna macrobéntica en un gradiente batimétrico: oeste del Golfo de México. Cienc. Mar., 25(2): 193-212.

Guerra-García, J.M. - 2003. Two new species of deep-water caprellids (Crustacea: Amphipoda) from northeastern Brazil. Cah. Biol. Mar., 44: 171-184.

Jarrett, N. E. and E.L. Bousfield. - 1994. The Amphipod Superfamily Phoxocephaloidea on the Pacific Coast of North America. Family Phoxocephalidae. Part II. Subfamilies Pontharpiniinae, Parharpiniinae, Brolginae, Phoxocephalinae, and Harpiniinae. Systematics and Distributional Ecology. Amphipacifica, 1(2): 71-149.

LeCroy, S. - 1995. Amphipod Crustacea III. Family Colomastigidae. Mem. Hourglass Cruises, 9: 1-139.

LeCroy, S. - 2000. An illustrated identification guide to the nearshore marine and estuarine gammaridean Amphipoda of Florida. Families Gammaridae, Hadziidae, Isaeidae, Melitidae and Oedicerotidae. Vol. 1. U.S. Environmental Protection Agency. WM724.
LeCroy, S. - 2001. An illustrated identification guide to the nearshore marine and estuarine gammaridean Amphipoda of Florida. Families Ampeliscidae, Amphilochidae, Ampithoidae, Aoridae, Argissidae and Haustoridae. Vol. 2. U.S. Environmental Protection Agency. WM724.

Lowry, J.K. and H.E. Stoddart. - 1997. Amphipoda Crustacea IV. Families Aristiidae, Cyphocarididae, Endevouridae, Lysianassidae, Scopelocheiridae, Uristidae. Mem. Hourglass Cruises, 10(1): 1-148.

Lowry, J.K. - 1984. Maxillipius commensalis, a second species in the family Maxillipidae from Papua New Guinea (Amphipoda, Gammaridea). Crustaceana, 46(2): 195-201.

Márquez, J.C. and D. Bellan-Santini. - 1993. Biodiversity in the ecosystem of the Portuguese continental shelf : distributional ecology and the role of benthic amphipods. Mar. Biol., 115: $555-564$.

McCain, J.C. - 1968. The Caprellidae (Crustacea: Amphipoda) of the Western North Atlantic. Bull. U. S. Nat. Mus., 278(I-IV): 1-116.

McKee, B. A. and M. Baskaran. - 1999. Sedimentary Processes of Gulf of Mexico Estuaries. In: T.S. Bianchi, J.R. Pennock and R.R. Twilley (eds), Biogeochemistry of Gulf of Mexico Estuaries, pp. 63-85. John Willey and Sons, USA.

Miller, A. I. - 2000. Paleobiology Suppl 26 53-73.

Monreal-Gómez, M. and D. Salas de León. - 1997. Circulación y estructura termohalina del Golfo de México. In: M.F. Lavin (ed), Contribuciones a la Oceanografía Física en México, pp. 183-199, Monografía No. 3. Unión Geofísica Mexicana, México.

Morrone, J.J. - 1994. On the identification of areas of endemism Syst. Biol., 43(3): 438-441.

Morrone, J.J. - 2004. Homología biogeográfica: las coordenadas espaciales de la vida. Cuadernos del Instituto de Biología, Núm. 37, Universidad Nacional Autónoma de México, México.

Myers, A. - 1981. Amphipod Crustacea I. Family Aoridae. Mem. Hourglass Cruises, 5(5): 1-75.

Nixon, K.C. - 1999. Winclada V 0.9 .99 beta. University of Cornell, USA.

Ortiz, M. - 1991. Amphipoda Crustacea II. Family Bateidae. Mem. Hourglass Cruises, 8(1): 1-31.

Ortiz, M. - 1994. Clave gráfica para la identificación de familias y géneros de anfípodos del suborden Gammaridea del Atlántico Occidental tropical. An. Inst. Inv. Mar. Punta Betín, 23: 59-101.

Ortiz, M., F. Álvarez and I. Winfield. - 2002. Caprellid Amphipods: Illustrated key for the genera and species from the Gulf of Mexico and The Caribbean sea. Ediciones UNAMFESI, México.

Pielou, E.C. 1992. Biogeography. John Wiley and Sons, USA.

Rabalais, N.N., R.S. Carney and E. Escobar-Briones. - 1999. Overview of Continental Shelf Benthic Communities of the Gulf of Mexico. In: H. Kumpf,, K. Steidinger and K. Sherman (eds), The Gulf of Mexico Large Marine Ecosystem: Assessment, Sustainability, and Management. pp. 171-195. Blackwell Science, USA.

Roberts, H.H., R.A. McBride and J.M. Coleman. - 1999. Outer Shelf and Slope Geology of the Gulf of Mexico: an overview. In: H. Kumpf, K. Steidinger and K. Sherman (eds), The Gulf of Mexico Large Marine Ecosystem: Assessment, Sustainability, and Management. pp. 93-112. Blackwell Science, USA

Rosen, B.R. - 1988. From fossils to Earth history: Applied historical biogeography. In: A.A. Myers and P. Giller (eds), Analytical biogeography: an integrated approach to the study of animal and plant distributions. pp. 437-481. Chapman and Hall, London.

Thomas, J.D. - 1993. Identification Manual for marine Amphipoda (Gammaridea): I common coral reef and rocks, bottom amphipods of South Florida. Final Report DEP contract number SP290. Smithsonian Institution Press, Washington.

Thurston, M. - 2000. Benthic Gammaridea (Crustacea: Amphipoda) in the deep sea. Pol. Arch. Hydrobiol., 47(3-4): 353-377.

Welsh, S. and M. Inoue. - 2000. Loop Current rings and the deep circulation in the Gulf of Mexico. J. Geophys. Res., 105(7): 16951-16959.

Scient. ed.: J.E. Cartes 